(C) 2013

\author{
Крижко А. В., кандидат сільськогосподарських наук, \\ Кузнсцова Л. М., кандидат біологічних наук \\ Інститут сільського господарства Криму НААН
}

\title{
ВПЛИВ ІНСЕКТИЦИДІВ НА АКТИВНІСТЬ ФЕРМЕНТІВ ПЕРОКСИДАЗИ ТА ПОЛІФЕНОЛОКСИДАЗИ У ЛИСТКАХ РОСЛИН КАРТОПЛІ
}

\section{Рецензент - доктор сільськогосподарських наук Л. О. Чайковська}

\begin{abstract}
Визначено, щзо активність ферментів пероксидази та поліфенолоксидази у листках рослин картоплі залежить від виду інсектицидів і строку їх зберігання на поверхні листа. За дії біоінсектицидів на основі штамів B. thuringiensis 994 та 787 відмічено незначне i короткотривале підвищення активності ферментів через 6-8 діб після їх застосування, щзо може бути помірною фітоімунною реакцією рослин на обробку препаратами або свідчити про спроможність рослин зберігати окислювальний обмін на стабільному рівні й забезпечувати збільшення адаптаційних спроможностей рослинного організму. Обробка рослин хімічним інсектищидом «Каліпсо» не сприяє формуванню неспецифічної стійкості у рослин картоплі протягом усього періоду досліджень.
\end{abstract}

Ключові слова: інсектицици, Bacillus thuringiensis, ферменти, пероксидаза, поліфенолоксидаза, картопля, стійкість рослин.

Постановка проблеми. Загальновідомо, що використання інсектицидів у системі захисту агрокультур від шкідників може спричиняти різноманітний вплив на фізіологічний стан рослин. Масове застосування хімічних інсектицидів окрім позитивного ефекту призводить до нагромадження залишків пестицидів у вегетативних та генеративних органах рослини i, як наслідок, у продуктах харчування [5]. Мікробні засоби захисту рослин - особливо на біопрепарати на основі Bacillus thuringiensis - $€$ природним компонентом мікрофлори грунтів i, отже, іiі застосування в захисних заходах суттєво не порушує видову структуру біоценозів [7]. Патогенну дію B. thuringiensis пов'язують із токсинами та іншими метаболітами, які вона продукує. Відомо, що 3 усіх токсинів щонайменшт два ( $\beta$-ендотоксин (водорозчинний термостійких токсин нуклеотидної природи) та $\delta$-ендотоксин (параспоральні білкові кристали)) можуть впливати на рослини як потужні біологічні подразники, фактори, мобілізуючи фітоімунітет та процеси росту [10]. Таким чином, питання про вплив біоінсектицидів на фізіологічний стан рослини, зокрема їх стійкість до несприятливих умов зовнішнього середовища, потребує поглибленого вивчення.
Аналіз основних досліджень і публікацій, у яких започатковано розв'язання проблеми. Зміни міри співвідношення активності окислювальних систем мають пристосувальне значення й можуть розглядатися як необхідні умови прояву стійкості рослин [9]. Такі зміни можуть бути пов'язані з коливанням умов зовнішнього середовища, зараженням інфекційними агентами, механічними пошкодженнями, які, в свою чергу, спричиняють вплив на функціонування ферментних систем рослини, включаючи порушення у життєдіяльності клітин і всього організму.

Взаємодія ферментів пероксидази та поліфенолоксидази в рослинах відбувається на функціональному рівні. Активування таких ферментів $€$ результатом новоутворювання додаткових кількостей білків, що володіють каталітичною активністю [6]. Лабільність пероксидази та поліфенолоксидази дає змогу використовувати їх як маркери для більш повної характеристики захисних механізмів рослин [12]. Пероксидази забезпечують нормальний хід окислювальних процесів за різноманітного негативного впливу на рослину. За дії несприятливого впливу чинників зовнішнього середовища пероксидази змінюють свою активність паралельно зі збільшенням ступеню техногенного пресу на рослини, що дозволяє припускати їх взаємну обумовленість $[2,8]$.

Водночас із пероксидазою в окисленні фенольних сполук з утворенням відповідних хінонів бере участь і поліфенолоксидаза [9]. Даний ензим не входить до складу антиоксидантних систем, але відіграє важливу роль у реакціях на несприятливі природні умови. У стресових умовах збільшується активність фенолоксидаз, що призводить до утворень захисних бар'єрів механічної або хімічної природи [4].

Як зміни умов зовнішнього середовища можливо розглядати й застосування біологічних інсектицидів у технологіях захисту рослин від шкідників. Відомо, що в результаті обробки рослин біопрепаратами на основі B. thuringiensis спори і токсини бактерій можуть зберігатися в 


\section{СІЛЬСЬКЕ ГОСПОДАРСТВО. РОСЛИННИЦТВО}

агробіоценозах тижнями [14], місяцями та роками як компонент природної мікрофлори [15]. На верхній стороні листа ентомопатогенні компоненти спостерігаються протягом 1-5 днів, а на нижній (захищеній від світла) - до 7-10 днів [16]. Тривалий період збереження компонентів на листі в тій чи іншій мірі може впливати на фізіологічні процеси, що відбуваються у тонопласті рослинної клітини. Одним із показників даного процесу може бути пероксидаза, яка здебільшого локалізується у клітинах оболонки епідермісу, замикаючих клітинах устячка та провідної тканини. Можна чекати, що вона відреагує на зміни зовнішніх умов у перші 5-13 діб [11].

Мета і завдання дослідження. Виходячи 3 вищезазначеного, метою нашої роботи було дослідження впливу біологічних інсектицидів на основі В. thuringiensis на активність ферментів пероксидази та поліфенолоксидази рослин картоплі в порівнянні з хімічним інсектицидом «Каліпсо 480 SC, к.с.».

Для виконання мети ставилися наступні завдання:

- дослідити динаміку активності ферментів пероксидази та поліфенолоксидази з 2-ї по 12-у добу після обробки рослин картоплі біоінсектицидами «ВТ 994» та «ВТ 787» на основі штамів В. thuringiensis 994 та 787 і хімічним інсектицидом «Каліпсо»;

- виявити вплив обробок інсектицидами на адаптаційні властивості рослин картоплі до умов зовнішнього середовища.

Матеріали та методи досліджень. Матеріалом для досліджень послужили біоінсектициди «ВТ 994» та «ВТ 787» на основі штамів В. thuringiensis 994 та 787. Штами одержані з Колекції корисних грунтових мікроорганізмів для підвищення урожайності сільськогосподарських культур ICГМ НААН і виділені з комах природних популяцій у лабораторії мікробіометоду відділу мікробіології Інституту сільського господарства Криму НААН. Штам В. thuringi-ensis 994 продукує $\delta$-ендотоксин та $\beta$-екзо-токсин, штам В. thuringiensis $787-\delta$-ендотоксин. Дія ентомопатогенних бактерій порівнювалася 3 дією хімічного інсектициду «Каліпсо $480 \mathrm{SC}$, к.с.», діючою речовиною якого є неонікотиноїд тіаклоприд. Дослідження проводили на рослинах картоплі сорту Явір в умовах польового досліду. Картоплю обробляли рідкими формами препаратів у фазі сходів. В якості контролю використовували рослини, оброблені водою. Аналіз листя 3 оброблених рослин проводили через кожні дві доби протягом дванадцяти діб після обробки. Активність пероксидази визначали за методом А. Н. Бояркіна, використовуючи в якості субстрату бензидин. Дані розраховували у відносних одиницях на 1 мг білку, або на 1 г си- рої тканини. Аналогічним методом визначали поліфенолоксидазу, використовуючи субстрат парафенілендіамин [3]. Достовірність різниці між дослідними та контрольними варіантами оцінювали за критерієм Стьюдента.

Результати досліджень. У процесі вивчення динаміки активності ферментів пероксидази аналізи, проведені через дві доби після обробки рослин, показали відсутність змін в активності ферменту в листках, оброблених як «ВТ 994» $\mathrm{i}$ «ВТ 787», так і «Каліпсо» (рис. 1). Далі, на 4-у добу, в досліджуваних зразках спостерігали зниження активності пероксидази, відповідно, на 11,$0 ; 10,3$ i 13,9 \%. Дані, отримані на 6-у добу досліду, констатували збільшення активності пероксидази у варіантах з обробкою «ВТ 994» та «ВТ 787» на 18,8 та 23,1\% відповідно, в той час як за обробки рослин «Каліпсо» тенденція до зниження активності ферменту зберігалася й становила 16,8 \%. На 8-у добу в листках рослин картоплі відмічали відновлення процесу зниження активності ферменту за обробки «ВТ 994», «ВТ 787» і «Каліпсо» на 32,0; 28,5 і 47,3 \% відповідно. У подальшому, на 10-у та $12-$ у доби досліджень, динаміка активності пероксидази значно відрізнялася по варіантах. На 10-у добу підвищення показника активності за дії біопрепаратів спостерігали у варіанті з рослинами, обробленими «ВТ 994» (на 20,4 \%), обробка ж рослин «ВТ 787» істотних коливань активності ферменту не спричиняла. Хімічний інсектицид «Каліпсо» дещо втрачав вплив на пероксидазу й стимулював зниження активності ферменту не менше ніж на 10,8 \%. У зразках же, відібраних на 12-у добу, у варіанті з «ВТ 994» істотних коливань активності пероксидази відмічено не було. Водночас відмічали позитивну динаміку активності ферменту в листках за обробки рослин «ВТ 787» на 19,6 \%. У ході обробки рослин «Каліпсо» показник активності ферменту залишався без змін. Періодичне помірне коливання активності пероксидази в листках, оброблених B. thuringiensis, можна пояснити фітоімунологічною відповіддю рослинних клітин на контакт із чужорідним мікробним агентом, який рослини не сприймають як суттєвий стрес-фактор, адже, на думку В. А. Андрєєвої [1], пероксидаза активізується за багатьох змін та порушень метаболізму рослин, а деякі ізоензими у відповідь на стрес синтезуються de novo. 3 літератури відомо, що незначні підвищення пероксидази в листках картоплі, які ми спостерігали в період досліджень, стимулюють фітоімунітет і ріст рослин, підвищуючи їх комплексну стійкість [13]. 


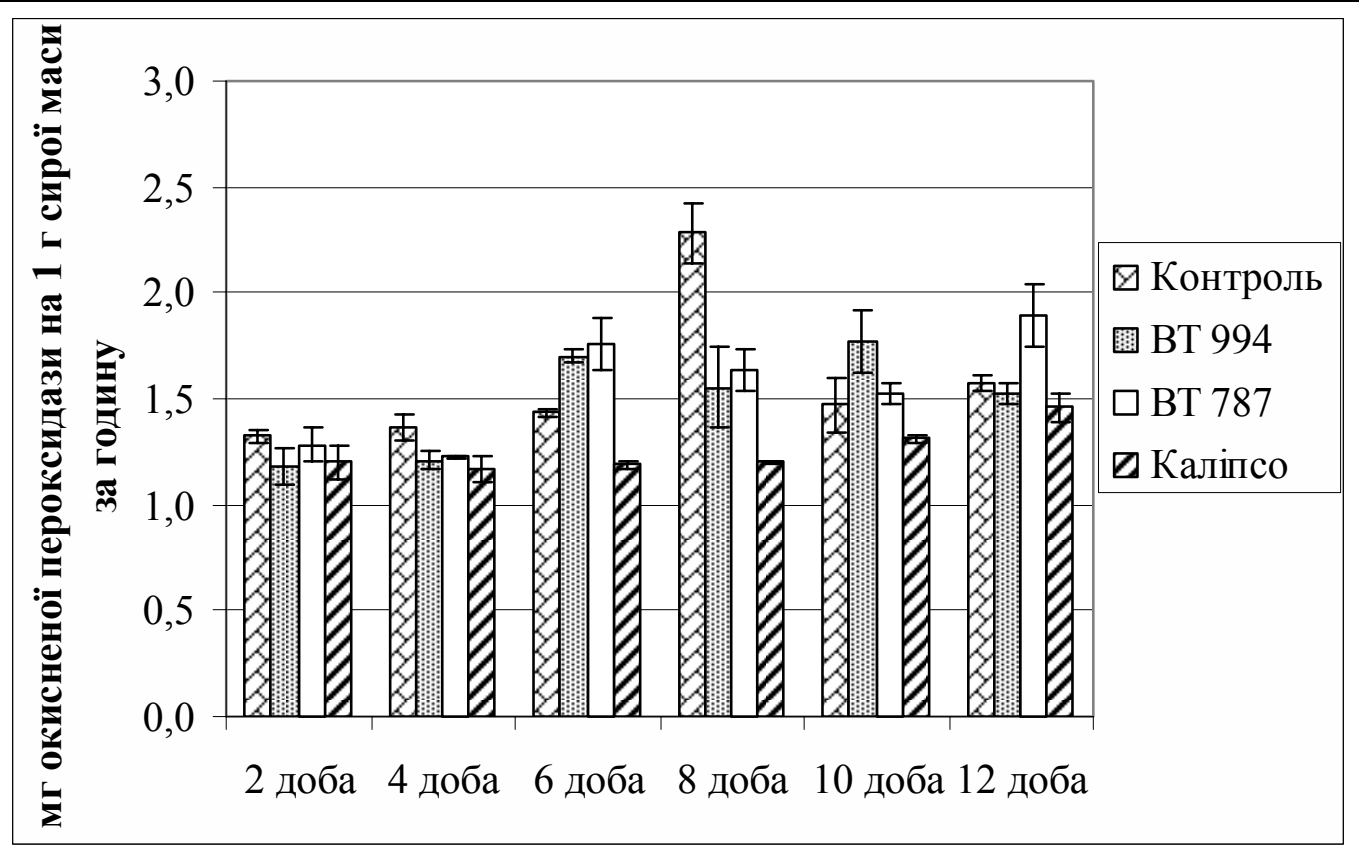

Рис. 1. Вплив інсектицидів на активність пероксидази у листках картоплі (польовий дослід, 2010 р.)

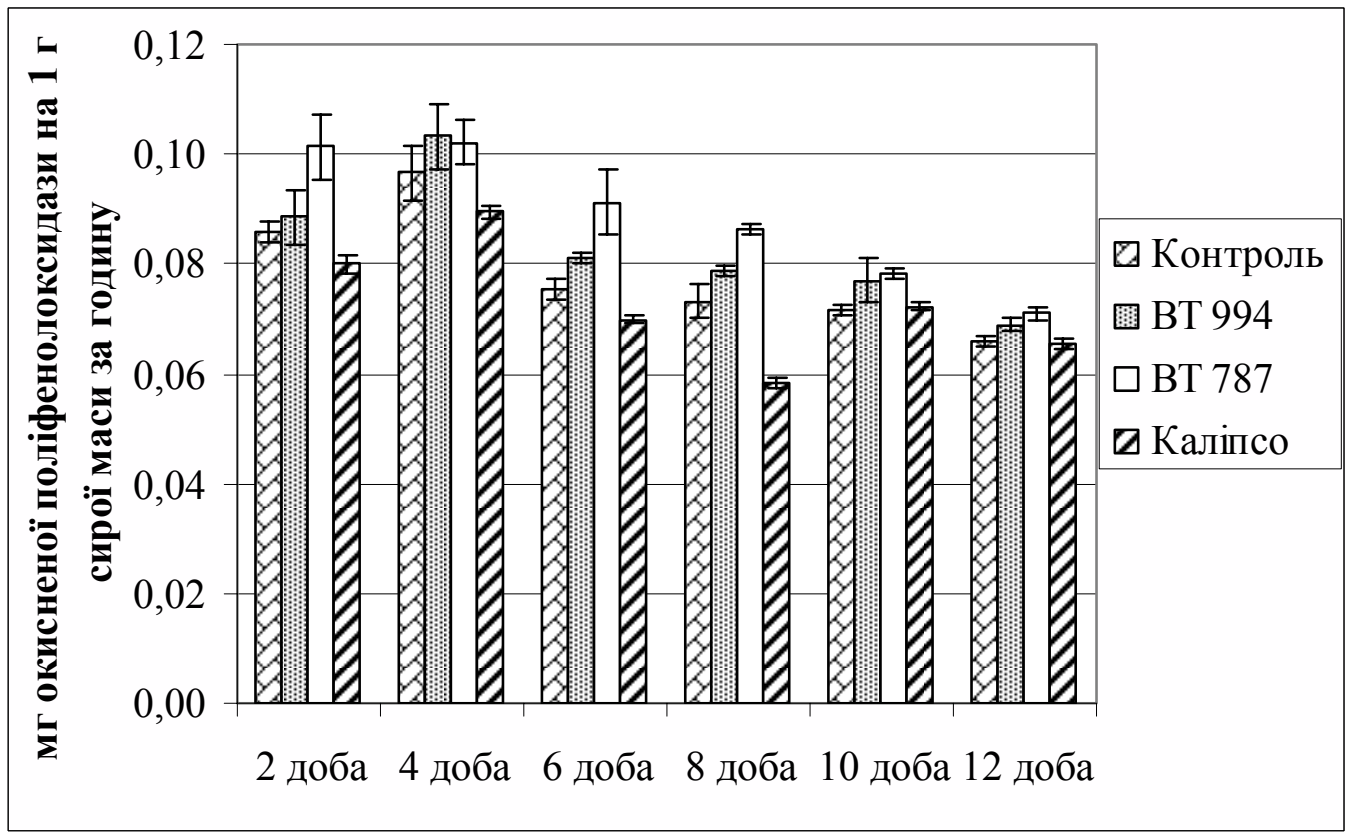

Рис. 2. Вилив інсектицидів на активність поліфенолоксидази у листках картоплі (польовий досліо, 2010 р.)

Зменшення ж активності ферменту, яке відмічено за дії хімічного інсектициду «Каліпсо», може свідчити про пригнічення адаптаційних можливостей організму рослин. У процесі вивчення динаміки активності поліфенолоксидази виявлено, що впродовж перших чотирьох діб досліду обробка рослин біоінсектицидами «ВТ 994» та «ВТ 787» та «Каліпсо» не спричиняє істотного впливу на активність ферменту (рис. 2). За дії «Каліпсо» за такий період спостерігали незначне зниження активності поліфенолоксидази (максимально - до 4,41 \%). Результати аналізу, проведеного на 6-у добу після застосування інсектицидів, як і раніше, не показали істотного впливу на активність поліфенолоксидази в листках рослин картоплі, обробленої «ВТ 994». $\mathrm{У}$ той же час активність ферменту в листях варіанта 3 «ВТ 787» підвищувалася на 20,9 \%. Рослини, оброблені «Каліпсо», зберігали підвищений рівень активності ферменту (на 2,4 \%). 


\section{СІЛЬСЬКЕ ГОСПОДАРСТВО. РОСЛИННИЦТВО}

На 8-у добу у варіантах із «ВТ 994» та «ВT 787» підвищення активності поліфенолоксидази зростало на 7,8 й 18,0 \% відповідно. Під впливом «Каліпсо» спостерігали зниження активності поліфенолоксидази на 20,5 \%.

Дані, отримані на 10-12-у добу досліду, свідчили, що коливання активності поліфенолоксидази в усіх варіантах було несуттєвим. Проведене нами вивчення активності ферментів пероксидази та поліфенолоксидази дає змогу проаналізувати адаптаційні властивості рослин картоплі до умов зовнішнього середовища. За результатами, обробка рослин біоінсектицидами на основі B. thuringiensis сприяе лише незначному та короткотривалому коливанню активності вивчених ферментів, що може бути помірною фітоімунною реакцією рослин на обробку препаратами або свідчити про здатність рослин зберіга-

\section{БІБЛІОГРАФІЯ}

1. Андреева В. А. Фермент пероксидаза: Участие в защитном механизме растений / Андреева В. А. М. : Наука, 1988. - 128 с.

2. Василюк В. М. Активність пероксидази і каталази у сої, інокульованої Tn5-мутантами Bradyrhizobium japonicum / В. М. Василюк, О. Д. Кругова, Н. М. Мандровська, С. Я. Коць // Физиология и биохимия культ. растений. -2007 . - Т. 39, № 4. C. 334-342.

3. Гавриленко В. Ф. Большой практикум по физиологии растений. Фотосинтез. Дыхание / Гавриленко В. Ф., Ладыгина М. Е., Хандобина Л. М. - М. : Высш. школа, 1975. - 392 с.

4. Дыхательные ферменты / [Под ред. В. А. Энгельгардта]. - М. : Изд-во иностранной литературы. - 1952. - С. 235-266.

5. Срмолова Л. В. Розробка розрахункових моделей прогнозу небезпечності неонікотиноїдних інсектицидів / Л. В. Єрмолова, М. Г. Проданчук, І. В. Лепьошкін // Современные проблемы токсикологии. - 2007. - №1. - С. 27-29.

6. Окопный Н. С. Физиолого-биохимическое исследование патогенеза и устойчивости овощных растений к мелойдогинозу: автореф. дис. ... канд. биол. наук. / Н. С. Окопный. - Кишинев, 1976. $-28 \mathrm{c}$.

7. Патогены насекомых: структурные и функциональные аспекты / [Под ред. В. В. Глупова]. М. : Круглый год, 2001. - 736 с.

8. Рачковская М. М. Изменение активности некоторых оксидаз как показатель адаптации растений к условиям промышленного загрязнения / М. М. Рачковская, Л. О. Ким // Газоустойчивость растений. - Новосибирск: Наука, 1980. C. $117-126$. ти окислювальний обмін на стабільному рівні й забезпечувати збільшення адаптаційних спроможностей рослинного організму. Обробка рослин «Каліпсо» призводить до помірного, хоча стійкого зниження активності ферментів, що може свідчити про не чітко виражену, але тривалу активізацію катаболічних процесів у тканинах.

Висновок. Таким чином, на відміну від хімічного інсектициду «Каліпсо», обробка рослин картоплі біоінсектицидами на основі штамів B. thuringiensis 994 та 787 сприяє збільшенню стійкості таких рослин до несприятливих умов зовнішнього середовища, що, в свою чергу, дає можливість забезпечити надійні шляхи ведення екологічно безпечного сільського господарства i в значній мірі вирішувати актуальні екологічні проблеми.

9. Рубин Б. А. Физиология и биохимия дыхания растений / Б. А. Рубин, М. Е. Ладыгина. - М. : Издво Моск. ун-та, 1974. - 511 с.

10. Симонова A. А. Стимулирующее действие дельта-эндотоксина Bacillus thuringiensis kurstaki штамм Z-52 на ювенильные растении / А. А. Симонова, Д. А. Терехин, Л. Д. Терехина, Л. К. Каменек // Материалы II Международной научнопрактической конференции [«Постгеномная эра в биологии и проблемы»], (Казань, 15-16 сентября 2008 г.), - Казань, 2008. - С. 119-120.

11. Тарчевский И. А. Сигнальные системы растений / Тарчевский И. А. - М. : Наука, 2002. 294 c.

12. Чекуров В. М. Новые регуляторы роста / В. М. Чекуров, С. И. Сергеева, Л. Д. Жалиева // Защита и карантин растений. - 2003. - №9. C. 20-21.

13. Шакирова Ф. М. Неспецифическая устойчивость растений к стрессовым факторам и ее регуляция / Шакирова Ф. М. - Уфа : Гилем, 2001. - $160 \mathrm{c}$.

14. Mormak D. A. Study of Bacillus subtilis endospores in soil by use of a modified endospore stain / D. A. Mormak, L. E. Casida Jr // Appl. Environ. Microbiol. - 1985. - №49. - P. 1356-1360.

15. Pruett C. J. H. Effect of exposure to soil potency and spore viability of Bacillus thuringiensis / C. J. H. Pruett, H. D. Burges, C. H. Wyborn // J. Invertebr. Pathol. - 1980. - №35. - P. 168-174.

16. Reardon R. C. Efficacy and field persistence of Bacillus thuringiensis after ground application to balsam fir and white spruce in Wisconsin / R. C. Reardon, K. Haissig // The Canadian Entomologist. - 1984. Vol.116. - P. 153-158. 